\title{
PRZETWARZANIE ODPADÓW KOMUNALNYCH I TWORZYW SZTUCZNYCH NA PALIWA PLYNNE - TECHNOLOGIE WtL
}

\author{
IZABELA SAMSON-BRĘK' \\ Przemysłowy Instytut Motoryzacji
}

\section{Streszczenie}

Na obecnym poziomie rozwoju cywilizacyjnego pojawiają się nowe problemy związane z dostępnością źródeł energii. Obecnie potrzeby energetyczne zaspakajane są w głównej mierze przez paliwa kopalne. Jednak ich zasoby są ograniczone i według przewidywań wielu naukowców wkrótce mogą ulec wyczerpaniu. Co więcej energia uzyskana z paliw kopalnych powoduje znaczne pogorszenie stanu środowiska naturalnego, przyczyniając się do jego degradacji.

W świetle powyższych obaw i zagrożeń pojawia się zainteresowanie nowymi nośnikami energii, które mogły by stanowić uzupełnienie paliw kopalnych oraz dodatkowe źródło energii, a co za tym idzie zwiększyć bezpieczeństwo energetyczne kraju, jak również przyczynić się do poprawy stanu środowiska. Takie pożądane żródło energii mogą stanowić odpady komunalne, ze szczególnym uwzględnieniem tworzyw sztucznych.

W niniejszej pracy zaprezentowane zostaną dwie perspektywiczne metody wytwarzania paliw płynnych z odpadów komunalnych i tworzyw sztucznych takie, jak katalityczna bezciśnieniowa depolimeryzacja (KDV) oraz plazmowe unieszkodliwianie odpadów.

Słowa kluczowe: odpady komunalne, paliwa płynne, tworzywa sztuczne, WtL.

\section{Wprowadzenie}

Na obecnym poziomie rozwoju cywilizacyjnego pojawiają się nowe problemy związane z dostępnością źródeł energii. Obecnie potrzeby energetyczne zaspakajane są w głównej mierze przez paliwa kopalne $[E, F]$. Jednak ich zasoby są ograniczone i według przewidywań wielu naukowców wkrótce mogą ulec wyczerpaniu. Co więcej energia uzyskana z paliw kopalnych powoduje znaczne pogorszenie stanu środowiska naturalnego, przyczyniając się do jego degradacji.

\footnotetext{
'Przemysłowy Instytut Motoryzacji, Zakład Odnawialnych Zasobów Energii, ul. Jagiellońska 55, 03-301 Warszawa, e-mail: i.samson@pimot.org.pl, tel.: 227777214
} 
W świetle powyższych obaw i zagrożeń pojawia się zainteresowanie nowymi nośnikami energii, które mogły by stanowić uzupełnienie paliw kopalnych oraz dodatkowe źródto energii, a co za tym idzie zwiększyć bezpieczeństwo energetyczne kraju, jak również przyczynić się do poprawy stanu środowiska. Takie pożądane źródło energii mogą stanowić odpady komunalne, ze szczególnym uwzględnieniem tworzyw sztucznych [C, D].

Wytwarzanie paliw płynnych z tworzyw sztucznych na chwilę obecną, przy dostępnych na rynku technologiach, nie jest procesem opłacalnym z ekonomicznego punktu widzenia, jednak pozwala na zagospodarowanie znacznej masy odpadów, a w ten sposób przybliża Polskę do osiągnięcia pewnego obligatoryjnego poziomu recyklingu wynikającego z regulacji Unijnych w zakresie gospodarki odpadami. Do 2020 roku Polska ma osiągnąć $50 \%$ poziomu recyklingu i przygotowania do ponownego użycia papieru, metali, tworzyw sztucznych i szkła, inaczej grozi nam płacenie wysokich kar za każdy procent nieosiągniętego poziomu $[A, B]$. Ponadto Polska będzie musiała zmniejszyć ilość składowisk odpadów komunalnych do 200 w 2014 roku. Jest to zadanie trudne, jednak możliwe do wykonania.

Wyróżnia się dwie podstawowe metody wytwarzania paliw płynnych z tworzyw sztucznych. W pierwszej metodzie wyselekcjonowane i odpowiednio przygotowane tworzywa sztuczne ogrzewane są do temperatury $400-500^{\circ} \mathrm{C}$, a następnie poddawane dalszej obróbce. Druga metoda natomiast polega na mieszaniu odpadów z olejem pochodzenia naftowego, a następnie poddawaniu działaniom wysokich temperatur. W obu przypadkach niezbędne jest zastosowanie odpowiednich katalizatorów. Końcowym efektem omawianych procesów jest powstanie paliw płynnych.

Celem niniejszej pracy jest analiza możliwości wykorzystania odpadów komunalnych, w tym odpadów z tworzyw sztucznych, jako surowce do produkcji paliw płynnych oraz pokazanie korzyści z zakresu zarówno względów środowiskowych, jak bezpieczeństwa energetycznego.

\section{Stan gospodarki odpadami w Polsce}

Polska to szósty największy wytwórca odpadów w Unii Europejskiej. W ostatnich latach w Polsce gospodarka odpadami uległa znacznym modyfikacją. Podstawą tych zmian jest w szczególności Dyrektywa Rady 99/31/WE w sprawie składowisk odpadów [B] oraz 2008/98/WE w sprawie odpadów - tzw. dyrektywa ramowa [A]. Dyrektywy te nakładają na państwa członkowskie obowiązek zmniejszenia ilości składowanych odpadów oraz prowadzenie gospodarki odpadami zgodnej z zasadami zrównoważonego rozwoju. Realizacja postanowień Dyrektywy jest w przypadku Polski bardzo trudna ze względu na brak wystarczającej ilości instalacji do odzysku i unieszkodliwiania odpadów, co z kolei przekłada się na niewielką ilość odpadów, która wykorzystywana jest jako surowiec energetyczny. W Polsce niestety nadal jedną z podstawowych metod unieszkodliwiania odpadów jest ich składowanie.

Jak wynika ze Sprawozdania z Realizacji Krajowego Planu Gospodarki Odpadami 2010 za Okres od dnia 1 Stycznia 2009 r. do dnia 31 Grudnia 2010 r. w 2010 r. w Polsce zebrano 
10044 tys. Mg ogółem odpadów komunalnych, z czego 6896 tys. Mg (68,6\%) pochodziło z gospodarstw domowych. Natomiast zmieszanych odpadów komunalnych zebrano 9184 tys. Mg, w tym 2392 tys. Mg (26,04\%) pochodziło z handlu, małego biznesu, biur i instytucji, zaś 494 tys. Mg (5,4\%) z usług komunalnych. Z terenu miast zebrano 80,85\% odpadów, a z obszarów wiejskich 19,15\%.

Na składowiskach zdeponowano 7369 tys. Mg (73,37\%) zebranych odpadów komunalnych, biologicznie unieszkodliwiono 609 tys. Mg (6,06\%), zaś termicznie tylko 102 tys. Mg $(1,01 \%)$. Ze zmieszanych odpadów komunalnych wysegregowano 1105 tys. Mg (11,00\%) odpadów i przekazano do dalszego wykorzystania [G].

Pozostałe odpady komunalne zostały wyselekcjonowane „u źródła" i selektywnie zebrane - w roku 2010 selektywnie zebrano 860 tys. Mg odpadów komunalnych, co stanowiło 8,56\% wszystkich odpadów komunalnych zebranych ogółem. Wśród wyselekcjonowanych odpadów stałych największą ilość stanowiły: szkło (25,1\%), odpady ulegające biodegradacji $(21,0 \%)$ oraz papier i tektura $(19,8 \%)$. Najwięcej odpadów wyselekcjonowano w województwach: mazowieckim, śląskim i dolnośląskim, a najmniej w województwach: podlaskim, opolskim i lubuskim [G].

W porównaniu do roku 2009, w roku 2010 zwiększył się udział odpadów zebranych selektywnie z 7,85\% do 8,56\%. Zmniejszyła się natomiast ilość deponowanych na składowiskach odpadów z 78,18\% do 73,37\% [G]. Dane te nie są optymistyczne, jednakże wynika z nich, że gospodarka odpadami w Polsce zmienia się i zmiany te podążają w słusznym kierunku.

\section{Technologia KDV - produkcji oleju napędowego z odpadów}

Katalityczna bezciśnieniowa depolimeryzacja (KDV) jest innowacyjną i względnie przyjazną środowisku technologią produkcji alternatywnych paliw płynnych z odpadów. Technologia ta umożliwia z wszystkich rodzajów substratów zawierających węglowodory, zarówno pochodzenia organicznego jak i mineralnego, wytworzyć olej napędowy, nafty oraz benzynę. Twórcą technologii jest niemiecki chemik oraz założyciel firmy Alphakat $\mathrm{GmbH}$, dr Christian Koch (Web-03).

Węglowodory zawarte w materiale wsadowym ulegają rozkładowi pod wpływem katalizatora w obiegu zawiesiny olejowej o temp. $280-340^{\circ} \mathrm{C}$. Stopień wykorzystania węglowodorów zawartych w materiale wejściowym wynosi ponad $80 \%$, tak więc jest to proces o wysokiej efektywności (Web-03). Powstające pary oleju napędowego zostają odseparowane w kolumnie destylacyjnej, zaś pozostałości po procesie, których przetworzenie w olej napędowy nie jest możliwe zostają usunięte. Efektem końcowym procesu jest powstanie paliw płynnych, a także biokomponentów drugiej generacji (o ile surowcem będzie odpad biodegradowalny).

Do głównych zalet procesu katalitycznego uolejania, zaliczamy (Web-03):

- niską temperaturę procesu - proces konwersji zachodzi w temperaturze ok. $280^{\circ} \mathrm{C}$,

- wysoką sprawność przetwarzania wynosząca 80\%, 
- wysoką sprawność energetyczną - na potrzeby własne instalacji zużywane jest tylko ok. 10\% wyprodukowanego w niej paliwa,

- niską ilość odpadów i zanieczyszczeń emitowanych do środowiska głównie dzięki temu, iż proces zachodzi w relatywnie niskich temperaturach. Jedynymi odpadami powstającymi podczas procesu są: popiół w ilości ok. 3\% wsadu (zanieczyszczeń w zależności od stopnia zanieczyszczenia materiału wsadowego), $\mathrm{CO}_{2}$ w ilości od 10 do $40 \%$ oraz woda.

Pierwsze instalacje KDV funkcjonują już w Niemczech, Kanadzie, Hiszpanii oraz Meksyku (Fot. 1).

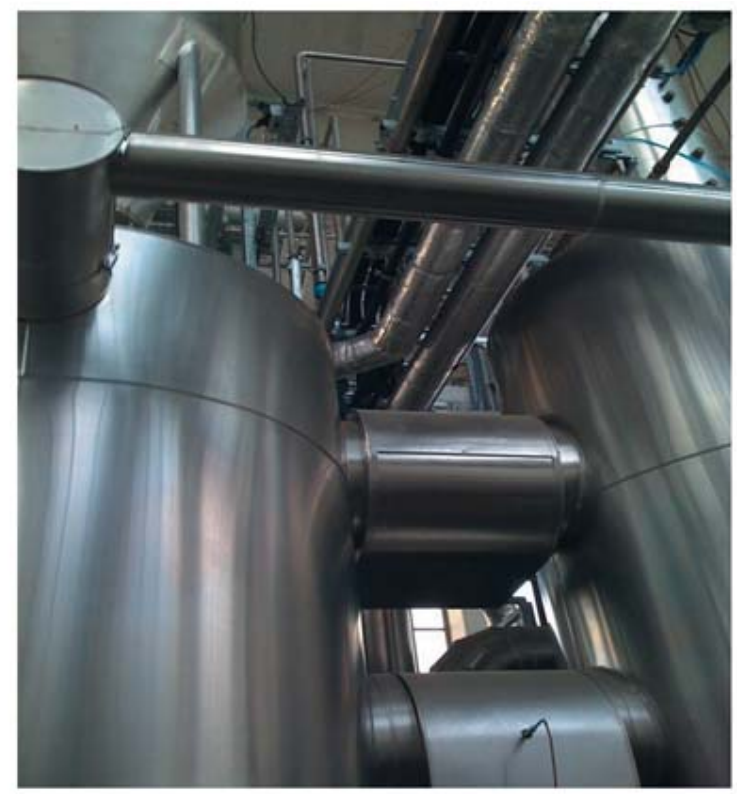

Fot. 1. Fragment działającej instalacji w Hoyerswerda, Niemcy Źródło: www.alphakatdiesel.pl/technologiakdv.html

\section{Plazmowe unieszkodliwianie odpadów}

Jedną z perspektywicznych technologii energetycznego wykorzystania odpadów jest technologia plazmowa, która pozwala na wytworzenie surowca energetycznego w postaci gazu syntezowego. Niekwestionowaną zaletą tej technologii jest możliwość odzyskania w 90\% energii wsadu, jak również neutralizacja i likwidacja substancji szkodliwych zawartych w odpadach dzięki zastosowaniu bardzo wysokich temperatur.

\subsection{Podstawy procesu plazmowego}

Plazma - czwarty stan skupienia - to zjonizowana materia będąca w stanie skupienia przypominającym gaz. Plazma składa się zarówno z cząstek naładowanych elektrycznie, 
jak i obojętnych, jednak w skali makroskopowej jest elektrycznie obojętna. Ze względu na zakres temperatur, w których występuje plazma możemy ją podzielić na dwa rodzaje [1]:

- plazmę zimną (4000-30 000 K) która powstaje w tzw. plazmotronach, czyli urządzeniach służących do wytwarzania plazmy o wspomnianych zakresach temperatur,

- plazmę gorącą (powyżej $30000 \mathrm{~K}$ ) występującą we wnętrzu gwiazd lub podczas wybuchów jądrowych.

Uzyskanie plazmy o wysokich zakresach temperatur powoduje powstanie nowych możliwości unieszkodliwiania opadów, jakich nie dają tradycyjne technologie spalania. Jest to spowodowane możliwością utylizacji odpadów w bardzo wysokich temperaturach dużo wyższych, niż te osiągane w zwykłych paleniskach, co z kolei przekłada się na rozkład substancji szkodliwych na składniki prostsze i bezpieczniejsze dla człowieka i środowiska. Technologia plazmowa, dzięki zastosowaniu wysokich temperatur oraz braku dostępu tlenu, pozwala na destrukcję polichlorowanych bifenyli (PCB), dichlorodiufenylotrichloroetanu (DDT), związków ołowiu, rtęci, kadmu oraz zapobiega powstawaniu dioksyn i furanów [2].

Technologia plazmowa znajduje zastosowanie w unieszkodliwianiu nie tylko odpadów niebezpiecznych takich, jak skażona gleba, odpady wojskowe czy odpady zawierające PCB czy DDT, ale również na utylizację odpadów komunalnych oraz większości odpadów organicznych.

Istotą neutralizacji i likwidacji aktywnych substancji chemicznych zawartych w odpadach jest wykorzystanie plazmy do atomizacji (czyli rozdziału substancji jednorodnej na elementy podstawowe), utleniania i przekształcania produktów procesu w związki mało aktywne bądź nieaktywne. Doprowadzenie do reaktora (Rys. 1), w którym zachodzą procesy

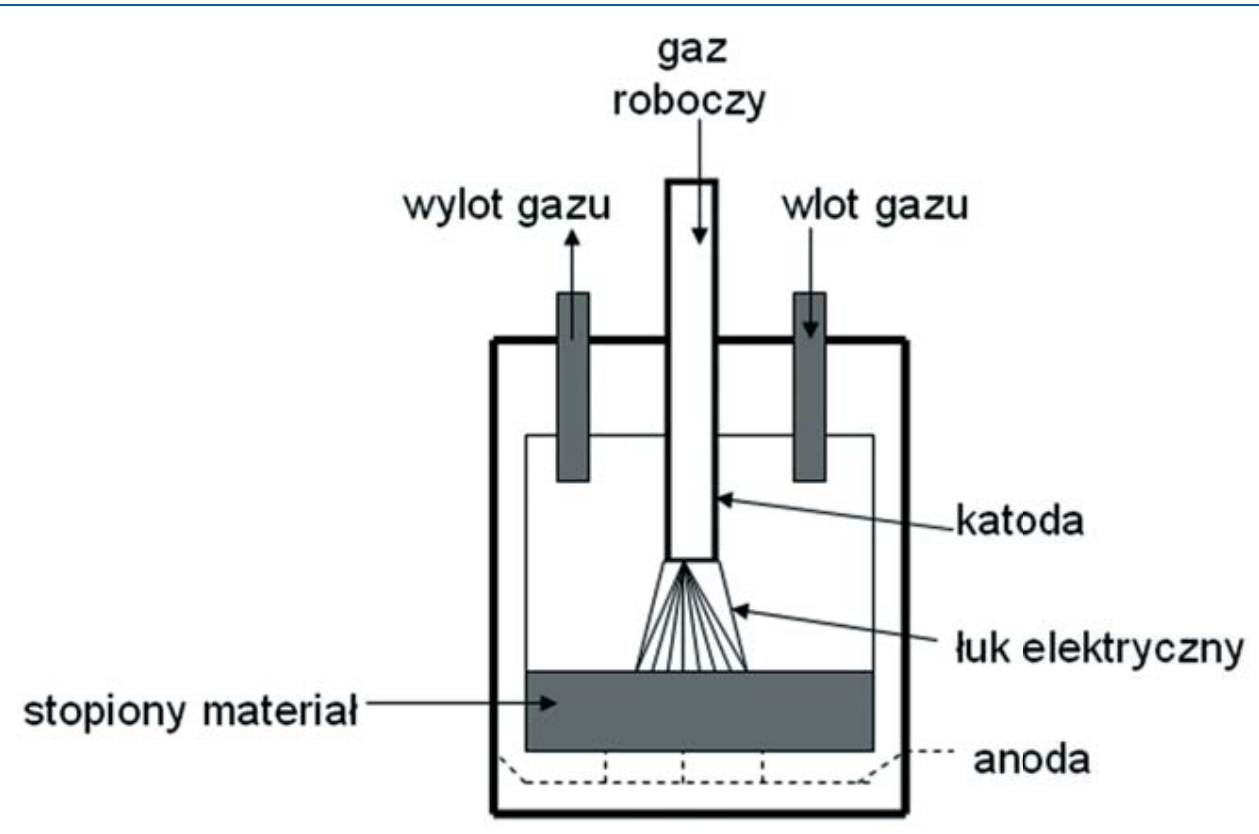

Rys. 1. Schemat reaktora plazmowego Źródło: Opracowanie własne 
plazmowego przekształcania i unieszkodliwiania opadów, tlenu pozwala na pełne utlenienie odpadu oraz otrzymanie produktów końcowych w formie spieku, żużla lub witroli. W tym celu do reaktora wprowadza się również substancje stabilizujące, które wiążą produkty końcowe i powodują ich zespolenie.

Bardzo ważnym produktem powstającym podczas unieszkodliwiania odpadów metodą plazmową jest syngaz, czyli gaz syntezowy. Syngaz jest gazem palnym powstającym w procesie syntezy Fischera-Tropscha (synteza F-T). Jest to katalityczna reakcja chemiczna powstawania węglowodorów z mieszaniny tlenku węgla i wodoru. Celem syntezy F-T jest produkcja paliw mających zastosowana w energetyce oraz transporcie.

\section{Metoda plazmowa II generacji i koncepcja zielonej elektrowni}

Rozwój technologii plazmowej umożliwił produkcję gazu syntetycznego wykorzystywanego między innymi do wytwarzania energii elektrycznej w sposób bezpieczny dla środowiska. W koncepcji tzw. zielonej elektrowni rozwijanej przez firmę General Plasma, która działa w oparciu o technologię plazmową II generacji (MPIIG), substratem mogą być odpady zmieszane w postaci: biomasy, węgla, węglowodorów, wszelkiego rodzaju odpadów komunalnych i przemysłowych. Cechą charakterystyczną tej metody jest bark konieczności segregacji odpadów przed ich podaniem do reaktora.

W zielonej elektrowni następuje odzyskanie energii wsadu w ok. 97\% (Web-01) w postaci syngazu wykorzystywanego do produkcji energii elektrycznej i ciepła, które stanowią końcowy produkt procesu.

Instalacja MPIIG składa się z szęciu najważniejszych elementów (Rys. 2) (Web-01). Należą do nich:

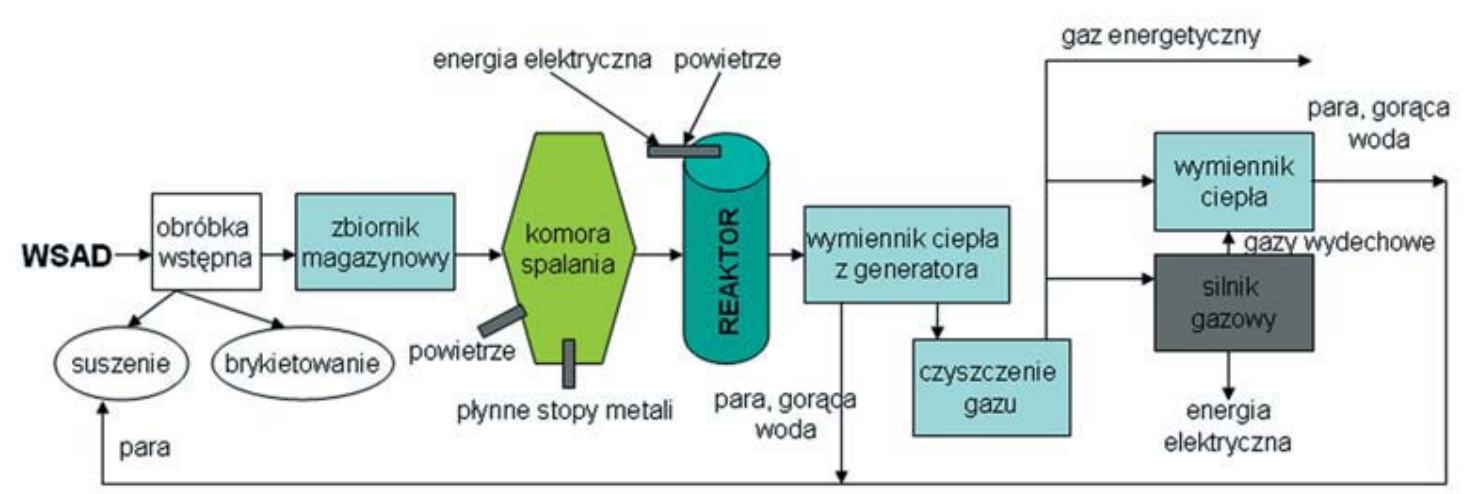

Rys. 2. Schemat instalacji MPIIG

Źródło: opracowanie własne na podstawie: http://www.generalplasma.com.pl 
- sekcja przyjęcia i przygotowania wsadu,

- sekcja termiczna z generatorem plazmy,

- reaktor,

- wymienniki ciepła (schładzania gazu),

- urządzenie do oczyszczanie gazu,

- sekcja energetyczna (przetwarzana na energię elektryczną lub cieplną).

Wsad stały w postaci odpadów dostarczany jest do sekcji przygotowania i wstępnej obróbki, gdzie w zależności od potrzeb jest rozdrabniany (w przypadku surowca o dużych rozmiarach), prasowany lub brykietowany (w przypadku surowca nie przekraczającego $1 \mathrm{~mm}$ ) i przesyłany do gazyfikatora. Wsad płynny nie wymaga obróbki i jest kierowany bezpośrednio do komory gazyfikacji (Web-01).

Surowiec zarówno w postaci stałej jak i płynnej wprowadzany jest do gazyfikatora przez zespół śluz, które zapobiegają przedostawaniu się na zewnątrz gazów pirolitycznych mogących zawierać substancje szkodliwe. Po wypełnieniu komory substratem, z generatora plazmy do gazyfikatora, wprowadzony jest gaz o temperaturze sięgającej $3000-5000^{\circ} \mathrm{C}$ powodując rozkład termiczny nawet najbardziej toksycznych związków (Web-01).

Powstały podczas procesu pirolizy gaz kierowany jest z reaktora do wymienników ciepła, gdzie podlega chłodzeniu do temperatury ok. $800^{\circ} \mathrm{C}$. Ciepło gazu jest odzyskiwane w procesie wymiany ciepła i służy następnie do wytwarzania gorącej wody.

Po schłodzeniu gaz kierowany jest do systemu oczyszczania, który składa się ze skrubera wodnego (wymywanie zanieczyszczeń gazowych głównie chlorowodoru i ditlenku siarki), sorbentu w postaci węgla aktywnego (usuwanie metali ciężkich) oraz filtra elektrostatycznego. Gaz syntetyczny po oczyszczeniu daje możliwość odzyskania 60-70\% energii z wsadu, natomiast kolejne $20-30 \%$ energii wsadu może być odzyskane jako energia ciepIna. Ze spalania $1 \mathrm{Nm}^{3}$ uzyskanego paliwa gazowego otrzymywana jest $1 \mathrm{kWh}$. Otrzymany gaz $w$ końcowym etapie jest sprężany $i$ gromadzony $w$ zbiornikach magazynujących (Web-01).

\section{Technologia WtL w Polsce}

W Polsce funkcjonują już pierwsze instalacje pozwalające na wytwarzanie paliw płynnych z odpadów. Jedna z takich instalacji jest w posiadaniu firmy Akropos (Fot. 2). Węglowodory powstają w reaktorze dwumodułowym na drodze procesu tzw. transformacji termokatalitycznej. Proces przetwarzania odpadów zachodzi na drodze transformacji katalitycznej wsadu w postaci odpadów z tworzy sztucznych. Surowcami do tego procesu są głównie poliolefiny. Materiał wsadowy mogą stanowić odpady z różnych gałęzi przemysłu takie, jak (Web-02):

- opakowania po środkach czystości oraz kosmetykach,

- folie, worki jednorazowego użytku oraz reklamówki,

- części opakowań produktów spożywczych,

- części urządzeń gospodarstwa domowego, 
- części przemysłu samochodowego, zderzaki, deski rozdzielcze,

- części tkanin przemysłowych,

- części techniki radiowo-telewizyjnej i komputerowej,

- części zabawek dla dzieci.

Pod wpływem wysokiej temperatury sięgającej ok. $500^{\circ} \mathrm{C}$, bez udziału powietrza, w warunkach ciśnienia atmosferycznego oraz przy udziale odpowiednich katalizatorów, następuje rozkład tworzyw sztucznych, czyli tzw. depolimeryzacja. Efektem reakcji depolimeryzacji jest rozpad polimerów w postaci poliolefin do monomerów.

Cechą charakterystyczną instalacji jest możliwość mieszania w dowolnych proporcjach odpadów z różną zawartością poliolefin, w tym również odpadów mokrych (do 40\% zawartości wody) oraz odpadów zawierających zanieczyszczenia w postaci piasku czy szkła oraz brak konieczności obróbki wstępnej wsadu. Obróbce wstępnej załadunku poprzez jego rozdrobnienie podawane są tylko odpady wielkogabarytowe załadunkiem powierzchni powyżej $100 \mathrm{~cm}^{2}$ (Web-02).

Załadunek surowca odbywa się ręcznie. Instalacja przetwarza średnio 400-450 tys. kg odpadów miesięcznie pracując w cyklu 24-godzinnym, osiągając w efekcie wynik na poziomie 220-330 tys. kg produktu finalnego w postaci komponentów paliw ciekłych. Mają one postać gęstej pasty, koloru jasnożółtego. W obrocie handlowym spotkać je można pod nazwą "Komponenty paliw płynnych o symbolice PKWiU24,66,32-90,00, CN 38,11" (Web02). Sprawność procesu osiąga poziom $62-78 \%$.

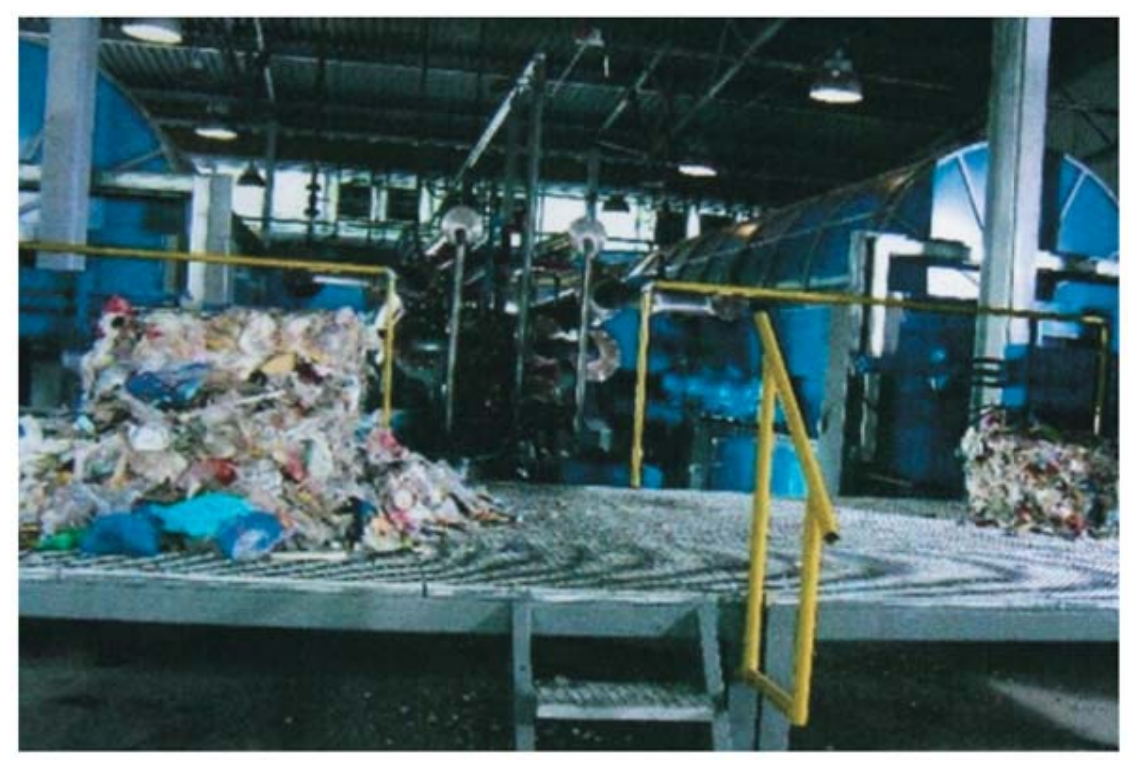

Fot. 2. Instalacja wytwarzania paliw płynnych na drodze transformacji termokatalitycznej posiadana przez firmę Akropos Żródło: http://www.plastech.pl/wiadomosci/artykul_1698_1/Technologia-przetwarzania-odpadow-na-komponent-paliw-plynnych 


\section{Wnioski}

Zagadnienia związane z energią ze źródeł odnawialnych, w tym również z energetycznym wykorzystaniem odpadów są ściśle związane z ochroną środowiska naturalnego oraz z koniecznością wzrostu bezpieczeństwa energetycznego poprzez produkcję energii ze źródeł niekonwencjonalnych. Energetyczne wykorzystanie odpadów daje również możliwość wywiązania się ze zobowiązań, jakie nakłada na Polskę Unia Europejska w zakresie udziału OZE w całkowitym bilansie energii pierwotnej oraz w zakresie zmniejszenia ilości składowanych odpadów komunalnych ulegających biodegradacji.

Katalityczna bezciśnieniowa depolimeryzacja (KDV) jest innowacyjną technologią produkcji alternatywnych paliw płynnych z odpadów. Dzięki zastosowaniu niskich temperatur do rozkładu polimerów podczas jej przebiegu nie powstają szkodliwe dla środowiska substancje jak dioksyny czy furany. Również ilość powstających odpadów stałych jest w znacznym stopniu minimalizowana. Wszystko to sprawia, że technologia KDV jest przyjazna środowisku.

Technologie plazmowe natomiast wykorzystują wysoką temperaturę plazmy sięgającą kilku tysięcy stopni Celsjusza, dzięki czemu wszystkie szkodliwe substancje są neutralizowane i wiązane przy udziale dodatków stabilizujących w żużlu, spieku lub witrolu. Produktem procesów plazmowych jest energia elektryczna, ciepło oraz gaz syntezowy, który może służyć do produkcji paliw transportowych.

Zarówno technologia KDV, jak i plazmowa są stosunkowo drogie i wymagają poniesienia wysokich kosztów inwestycyjnych związanych z budową instalacji, jej eksploatacją, a w przypadku "plazmy" również z wysokim zużyciem energii elektrycznej. Mimo to obie technologie traktowane są jako perspektywiczne i cieszą się coraz większym zainteresowaniem wśród potencjalnych inwestorów zarówno w Polsce jak i na świecie oraz mają szansę stać się jednymi z podstawowych technologii unieszkodliwiania odpadów oraz odzysku energii w nich zawartych.

Dla obydwu technologii konieczne jest również określenie a następnie wzrost wskaźnika EIOER (Energy Input over Energy Return).

\section{Bibliografia}

[1] Kyć K.: Analiza metod energetycznego wykorzystania odpadów, Wydział Wiertnictwa, Nafty i Gazu, Akademia Górniczo-Hutnicza, Krakowska Konferencja Młodych Uczonych 2008, Kraków 2008.

[2] "Innowacyjne technologie unieszkodliwiania odpadów", Informacja dla Sejmowej Komisji Ochrony Środowiska, Zasob6w Naturalnych i Leśnictwa, Ministerstwo Środowiska, Warszawa 2008.

\section{Dokumenty prawne}

A) Dyrektywa 2008/98/WE z dnia 19 listopada 2008 r. w sprawie odpadów oraz uchylająca niektóre dyrektywy.

B) Dyrektywa Rady 1999/31/WE z dnia 26.04.1999 r. w sprawie składowania odpadów.

C) Ustawa o odpadach z dnia 20 kwietnia 2001 r., (Dz. U. Nr 62, poz. 628).

D) Rozporządzenie Ministra Środowiska z dnia 27 września 2001 r. w sprawie katalogu odpadów. 
E) Polityka Energetyczna Polski do 2030 roku, opracowana przez Ministerstwo gospodarki, Warszawa 2009.

F) Prognoza zapotrzebowania na paliwa i energię do 2030 roku (Załącznik nr 2 do Polityki energetycznej Polski do 2030 roku), opracowana przez Ministerstwo Gospodarki, Warszawa 2009.

G) Sprawozdanie z Realizacji Krajowego Planu Gospodarki Odpadami 2010 za Okres od Dnia 1 Stycznia 2009 r. do Dnia 31 Grudnia 2010 r., Warszawa grudzień 2011.

\section{Strony internetowe}

(Web-01) http://www.generalplasma.com.pl, dostęp: 05.2012 r.

(Web-02) http://www.plastech.pl/wiadomosci/artykul_1698_2/Technologia-przetwarzania-odpadow-nakomponent-paliw-plynnych0, dostęp: 05.2012

(Web-03) http://www.alphakatdiesel.pl/technologiakdv.html, dostęp: 05.2012 r. 